\title{
PENYELESAIAN SENGKETA TANAH TERHADAP EIGENDOM VERPONDING YANG DIKUASAI PIHAK LAIN
}

\author{
Amelia Akef Abdat \\ Universitas Pembangunan Nasional "Veteran" Jakarta \\ Jl. RS. Fatmawati Raya, Pd. Labu, Kec. Cilandak, Kota Depok, Jawa Barat 12450 \\ Tel/Fax: 087721721056E-mail:ameliaakefabdat@upnvj.ac.id \\ Atik Winanti \\ Universitas Pembangunan Nasional "Veteran" Jakarta \\ Jl. RS. Fatmawati Raya, Pd. Labu, Kec. Cilandak, Kota Depok, Jawa Barat 12450 \\ Tel/Fax:082112212172 E-mail:atikwinanti@upnvj.ac.id
}

\begin{abstract}
Abstrak
Sejak diberlakukannya UUPA pada tanggal 24 September 1960 maka hak atas tanah eigendom verponding harus dikonversi menjadi hak milik untuk Warga Negara Indonesia dan hak guna bangunan untuk Warga Negara Asing dalam batas waktu 20 tahun sejak UUPA diberlakukan yaitu 24 September 1980. Namun pada praktiknya setelah 20 tahun UUPA diundangkan masih banyak pemilik hak atas tanah eigendom verponding yang belum mengkonversinya menjadi hak milik atau hak guna bangunan sehingga timbul sengketa penguasaan tanah oleh pihak lain tetapi pemiliknya masih memegang hak atas tanah eigendom verponding. Sehingga tujuannya dilakukan penelitian ini adalah untuk mengetahui dan memahami kekuatan pembuktian eigendom verponding terhadap sengketa tanah yang dikuasai pihak lain serta untuk mengetahui dan memahami cara mengembalikan hak atas tanah eigendom verponding yang dikuasai pihak lain. Metode penelitian yang digunakan dalam penelitian ini adalah metode yuridis normatif dan dapat diambil kesimpulan, bahwa: Kekuatan pembuktian eigendom verponding berdasaran PP Nomor 24 Tahun 1997 tentang Pendaftaran Tanah, hak atas tanah yang berasal dari hak-hak hukum Eropa termasuk didalamnya hak atas tanah eigendom verponding dapat didaftarkan dengan alat-alat bukti yang kuat untuk dikonversi menjadi hak milik walaupun telah melewati batas waktu konversi. Cara mengembalikan eigendom verponding yang dikuasai pihak lain dengan menggugat dan membuktikan ada kesalahan dalam proses penerbitan sertifikat yang menimbulkan tumpang tindih dan setelah digugat pemilik hak atas tanah eigendom verponding harus mengkonversinya menjadi hak milik. Sarannya kepada pemilik hak atas tanah eigendom verponding harus mengkonversi dengan mencantumkan alat bukti yang kuat. Serta kepada pihak BPN untuk lebih teliti dalam menerbitkan sertifikat agar tidak terjadi tumpang tindih dalam kepemilikan hak atas tanah.
\end{abstract}


Kata kunci: Eigendom verponding; hak atas tanah; pihak lain.

\begin{abstract}
Since the enactment of the UUPA on September 24th 1960, eigendom verponding land rights must be converted into property rights for Indonesian citizens and land use rights for foreign citizens within 20 years since the UUPA was enacted 24 September 1980. However, in practice after 20 years The UUPA was promulgated there are still many owners of eigendom verponding land rights who have not converted them to property rights or building use rights so that land tenure disputes arise by other parties but the owners still hold the rights to the eigendom verponding land. So that the purpose of this research is to find out and understand the power of proof of eigendom verponding against land disputes controlled by other parties and to know and understand how to return the rights to eigendom verponding land controlled by other parties. The research method used in this study is a normative juridical method and it can be concluded that: Eigendom verponding's evidentiary power is based on Government Regulation Number 24 of 1997 concerning Land Registration, land rights derived from European legal rights including eigendom verponding land rights can be registered with strong evidence to be converted into property rights even though the conversion deadline has passed. The way to return eigendom verponding which is controlled by another party is by suing and proving that there is an error in the certificate issuance process which causes an overlap and after being sued the owner of the eigendom verponding land rights must convert it into property rights. His suggestion to owners of land rights eigendom verponding must convert by including strong evidence. As well as to the BPN to be more careful in issuing certificates so that there is no overlap in ownership of land rights.
\end{abstract}

Keywords: Eigendom verponding, land rights, other parties.

\title{
A. Pendahuluan
}

Tanah adalah objek hukum yang sangat rentan terkena sengketa, baik sengketa antar para individu, individu dengan badan hukum, antar badan hukum, hingga dapat terjadi sengketa yang melibatkan pemerintah seperti BPN (Badan Pertanahan Nasional). Salah satu landasan hukum di Indonesia yang terkait dengan tanah adalah Pasal 33 ayat (3) Undang- Undang Dasar 1945 yang berbunyi: "Bumi dan air dan kekayaan alam yang terkandung di dalamnya dikuasai oleh negara dan dipergunakan untuk sebesar-besar kemakmuran 
rakyat". ${ }^{1}$ Sebelumnya berlakunya UUPA yang menjadi aturan adalah UU Agraria 1870 dan UU Kehutanan 1874, 1875, dan 1897 dengan berlakunya asas domein Negara yang menyebutkan bahwa tanah yang tidak mempunyai status pemilikan perseorangan sesuai dengan asas hukum Barat akan dianggap sebagai milik Negara. ${ }^{2}$

Asas domein Negara diubah menjadi konsep politico-legal baru yang disebut Hak Menguasai Negara pada saat UUPA diundangkan. Dalam konsep Hak menguasai Negara Pemerintah Pusat memiliki kekuasaan untuk mengatur terkait dengan penguasaan, pemilikan, penatagunaan, dan pemanfaatan tanah serta kekayaan alam. ${ }^{3}$ Saat UUPA diundangkan maka hak atas tanah yang terdapat dalam hukum Barat harus dikonversi dalam batas waktu 20 tahun setelah UUPA diundangkan. ${ }^{4}$ Pemerintah memberikan perlindungan hukum terhadap pemilik baru hak atas tanah bekas eigendom. ${ }^{5}$ Namun dalam praktiknya setelah 20 tahun UUPA undangkan masih banyak pihak-pihak yang memiliki hak atas tanah dari hukum Eropa (Barat). Apabila tanah-tanah hak barat tidak dilakukan konversi menjadi hak atas tanah sesuai dengan UUPA, maka tanah yang tidak dapat dibuktikan haknya menjadi tanah Negara sesuai dengan teori Domein Verklaring berdasarkan Pasal 1 Peraturan Menteri Dalam Negeri Nomor 3 Tahun 1979 tentang Ketentuan-Ketentuan Mengenai Permohonan dan Pemberian Hak Baru Atas Tanah Asal Konversi Hak-Hak Barat. ${ }^{6}$

${ }^{1}$ Pasal 33 ayat (3) UUD 1945.

2 Noer Fauzi Rachman, Land Reform dan Gerakan Agraria Indonesia (Yogyakarta: INSISTPress, 2017), h.45.

${ }^{3}$ Noer Fauzi Rachman, Land Reform Dari Masa Ke Masa (Yogyakarta: Tanah Air Beta, 2012), h.15-16.

4 Abdul Rahim Lubis dan Muhammad Yamin Lubis, Hukum Pendaftaran Tanah (Bandung: CV. Mandar Maju, 2008), h.218.

${ }^{5}$ Elza Syarief, Pensertifikatan Tanah Bekas Hak Eigendom (Jakarta:

Kepustakaan Popoler Gramedia, 2014), h.114.

6 William Seven Liadi, "Kedudukan Eigendom Verponding dalam Hukum 
Dalam masih banyak pemilik eigendom verponding sampai saat

ini, maka timbul permasalahan yaitu tanah tersebut dikusai oleh pihak lain namum pemiliknya masih memegang eigendom verponding. Seperti contohnya dalam putusan Nomor. 358/Pdt.G/2018/PN. Sby. Dalam putusan tersebut penggugat memiliki tanah eigendom dan surat-suratnya namun, tanah tersebut dikuasai oleh tergugat. Maka penggugat berhak untuk mendapatkan haknya kembali dengan cara mengajukan gugatan.

Dalam penelitian ini penulis akan fokus membahas eigendom verponding. Definisi dari eigendom verponding yaitu hak atas tanah yang diterbitkan pada zaman Belanda yang berasal dari hak-hak barat untuk Warga Negara Indonesia. Eigendom secara harfiah dapat diartikan sebagai hak milik tetap atas tanah dan verponding adalah surat tagihan pajak terhadap tanah atau tanah dan bangunan. Setelah UUPA berlaku Verponding tersebut menjadi surat pemberitahuan pajak terhutang pajak bumi dan bangunan (SPPTPBB). ${ }^{7}$ Dan menurut pasal 570 KUHPerdata hak eigendom bersifat mutlak dan pemiliknya dengan cara yang seluas mungkin dapat menikmati dan mempergunakan haknya. ${ }^{8}$ Dalam Pasal I ayat (1) Bagian Kedua Ketentuan-

Pertanahan di Indonesia" Jurnal Panorama Hukum 4, no. 1
(2019),h.14,http://ejournal.unikama.ac.id/index.php/jph/article/view/388 4/2360 (diakses tanggal 20 Oktober 2020)

7 Muhlizar, "Eigendom Verponding Sebagai Alas Hak Dalam Persfektif Undang-Undang Nomor 5 Tahun 1960 tentang Peraturan Dasar Pokok-

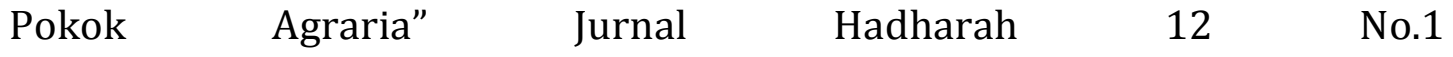
(2020),h.90,https://ejurnal.univamedan.ac.id/index.php/Hadharah/article/vie w/58/44 (diakses tanggal 20 Oktober 2020)

8 Muhammad Yamin Lubis dan Abdul Rahim Lubis, Pencabutan Hak, 
Ketentuan Konversi di UUPA hak eigendom verponding sejak berlakunya undang-undang ini harus dikonversi menjadi hak milik. ${ }^{9}$

Dengan dibataskan waktu untuk konversi selama 20 tahun yaitu sejak UUPA diberlakukan tertanggal 24 September 1960 terutama hak atas tanah eigendom verponding menjadi hak milik maka timbul permasalahan yaitu banyaknya pemilik eigendom verponding yang belum mengkonversi hak atas tanahnya menjadi hak milik setelah lewat batas waktu 20 tahun yaitu hingga 24 September 1980. Hak milik tersendiri hanya dapat dimiliki oleh Warga Negara Indonesia dan Bank Pemerintah, badan keagamaan, dan badan sosial. ${ }^{10}$ Dalam penelitian ini akan mengangkat dan fokus membahas banyaknya pemilik tanah yang memiliki hak atas tanah eigendom verponding namun, adanya ketidakjelasan hukum terkait dengan kekuatan pembuktiannya karena dalam Pasal 1 Peraturan Menteri Dalam Negeri Nomor 3 Tahun 1979 tentang Ketentuan-Ketentuan Mengenai Permohonan dan Pemberian Hak Baru Atas Tanah Asal Konversi Hak-Hak Barat menyebutkan jika dalam jangka waktu 20 tahun tidak dikonversi maka tanah tersebut dikuasai oleh negara namun, pada Pasal 24 Peraturan Pemerintah Nomor 24 Tahun 1997 tentang Pendaftaran Tanah disebutkan hak-hak lama termasuk eigendom verponding masih dapat didaftarkan atau dikonversi menjadi hak milik walaupun telah melewati batas waktu 20 tahun setelah UUPA diundangkan. Dan juga sengketa tanah yang terjadi dan sering ditemukan yaitu penguasaan tanah oleh pihak lain tetapi pemiliknya masih memegang hak atas tanah eigendom verponding.

Dari latar belakang diatas, penelitian ini akan merumuskan kekuatan

Pembebasan, dan Pengadaan Tanah (Bandung: CV. Mandar Maju, 2011), h.11.

9 Pasal I ayat (1) Bagian KeduaUndang-Undang No.5 Tahun 1960 tentang Peraturan Dasar Pokok-Pokok Agraria.

10 Diyan Isnaeni dan Suratman, Reforma Agraria Land Reform dan Redistribusi Tanah di Indonesia. (Malang: Intrans Publishing, 2018), h.149. 
pembuktian eigendom verponding terhadap sengketa tanah yang dikuasai pihak lain. Dan penelitian ini akan membahas cara mengembalikan hak atas tanah eigendom verponding yang dikuasai pihak lain. Dan tujuan dari penelitian ini adalah untuk mengetahui dan memahami kekuatan pembuktian eigendom verponding terhadap sengketa tanah yang dikuasai pihak lain serta untuk mengetahui dan memahami cara mengembalikan hak atas tanah eigendom verponding yang dikuasai pihak lain.

\section{B. METODE PENELITIAN}

Jenis penelitian yang digunakan dalam penelitian ini adalah yuridis normatif yang digunakan untuk mengkaji norma hukum atau kaidah norma yang berlaku dalam hukum positif dan untuk mengkaji asas-asas dan norma hukum yang terdapat dalam perundang-undangan kemudian diteliti pelaksanaan tersebut dari ketentuan-ketentuan dan dampaknya. Metode yuridis normatif ini menitikberatkan terhadap data kepustakaan atau data sekunder.

Pendekatan masalah yang digunakan dalam penelitian ini yaitu pendekatan perundang-undangan (statute approach) yaitu menelaah perundang-undangan yang bersangkutan dengan isu hukum serta pendekatan kasus (case approuach) yaitu melakukan telaah pada kasus yang berkaitan dengan isu hukum. Dalam pendekatan ini peneliti akan menyebutkan argumentasi hukum dengan kasus yang terjadi.

Cara pengumpulan data dilakukan dengan cara kepustakaan (library research).

Studi pustaka adalah metode pengumpulan data dengan cara pencarian informasi dan data seperti mengumpulkan data-data yang terdapat dari bukubuku, dokumen, majalah internet (webite), dan menganalisa data-data tersebut sehingga peneliti dapat merumuskan permasalahan yang dikaji.

Sumber data yang digunakan dalam penelitian ini adalah data sekunder yang meliputi:

1. Bahan Hukum Primer 
a. Undang-Undang Dasar Negara Republik Indonesia 1945;

b. Kitab Undang-Undang Hukum Perdata;

c. Undang-Undang Nomor 5 Tahun 1960 tentang Peraturan Dasar PokokPokok Agraria;

d. PP Nomor 24 Tahun 1997 tentang Pendaftaran Tanah;

e. Kepres Nomor 32 Tahun 1979 Jo. Permen Nomor 3 Tahun 1979 tentang Pokok-Pokok Kebijakan dalam Rangka Pemberian Hak Baru Atas Tanah Asal Konversi Hak-Hak Barat;

f. Peraturan Menteri Nomor 2 Tahun 1960 tentang Pelaksanaan Ketentuan Undang-Undang Pokok Agraria.

2. Bahan Hukum Sekunder
a. Buku-buku;
b. Hasil-hasil penelitian;
c. Jurnal ilmiah;
d. Hasil karya kalangan hukum.

Metode analisis data yang digunakan dalam penelitian ini yaitu metode kualitatif untuk memberikan penafsiran dan pemahaman mengenai kekuatan pembuktian eigendom verponding serta cara mengembalikan hak atas tanah eigendom verponding yang dikuasai pihak lain.

\section{PEMBAHASAN}

\section{Kekuatan Eigendom Verponding yang Dikuasai Pihak Lain}

Sebelum UUPA berlaku Indonesia memakai hukum tanah barat (eropa), dalam hukum tanah barat terdapat beberapa hak-hak atas tanah yaitu:

a. Hak Eigendom, merupakan hak menikmati suatu benda secara leluasa serta untuk berbuat terhadap barangnya itu secara seluruhnya, asalkan tidak berlawanan dengan undang-undang atau peraturan umum yang berlaku dan tidak mengganggu hak- hak orang lain. ${ }^{11}$ Jika berlawanan dengan undang-

${ }_{11}$ Pasal 570 Kitab Undang-Undang Hukum Perdata. 
undang maka hak tersebut dapat saja dicabut. Kekuatan hak eigendom merupakan hak tertinggi, namun hakikatnya hak milik dalam KUHPerdata tidak sama dengan hak milik dalam UUPA. Kekuatan hak eigendom merupakan hak yang bersifat mutlak bagi pemiliknya, sedangkan hak milik lebih mementingkan kepentingan umum dibanding perorangan. ${ }^{12}$ Diatur dalam Pasal 570 KUHPerdata.

b. Hak Opstal, merupakan hak kebendaan untuk memiliki bangunan ataupun tanaman diatas tanah milik orang lain atau hak eigendom. ${ }^{13}$ Diatur dalam Pasal 711 KUHPerdata.

c. Hak Erfpacht, merupakan hak untuk menikmati dan mengolah tanah orang lain yang memiliki kewajiban membayar tahunan terhadap pemilik tanah. ${ }^{14}$ Pemegang hak erfpacht berwenang untuk menjadikan tanahnya sebagai jaminan hutang dan mengalihkan kepada ahli warisnya sepanjang waktunya belum habis. ${ }^{15}$ Diatur dalam Pasal 720 KUHPerdata.

d. Hak Gebruik, merupakan seseorang diperbolehkan menarik seluruh hasil dari suatu hak kebendaan milik orang lain dengan memiliki kewajiban untuk memelihara tanahnya. ${ }^{16}$

12 Achmad Mu'in, “Hak Pemegang Hak Atas Tanah EigendomUntuk Mendapatkan Hak Setelah Habisnya Waktu Sebagaimana Keputusan Presiden Republik Indonesia Nomor 32 Tahun 1979 Tentang Pokok-Pokok Kebijaksanaan Dalam Rangka Pemberian Hak Baru Atas Tanah Asal Konversi Hak-Hak Barat." Calyptra.4 No. 1 (2015). h

ttp://journal.ubaya.ac.id/index.php/jimus/article/view/1020/819

(diakses tanggal 1 November 2020)

13 Pasal 711 Kitab Undang-Undang Hukum Perdata.

${ }_{14}$ Pasal 720 Kitab Undang-Undang Hukum Perdata

${ }^{15}$ Achmad Mu'in, Op.Cit.

${ }_{16}$ Ulfia Hasanah, "Status Kepemilikan Tanah Hasil Konversi Hak Barat Berdasarkan Uu No. 5 Tahun 1960 Tentang Peraturan Dasar Pokok-Pokok 
Setelah UUPA diberlakukan yaitu tanggal 24 Sepetember 1960 hak-hak barat yang berada dalam KUHPerdata tersebut tidak diberlakukan kembali, kecuali mengenai hak hipotek masih berlaku. UUPA berfungsi untuk menyediakan dan mengatur jenis-jenis hak atas tanah sebagai landasan hukum untuk penguasaan serta penggunaan tanah yang diperlukan meliputi Hak Guna Bangunan, Hak Pakai, Hak Guna Usaha, serta Hak Milik. ${ }^{17}$ Maka untuk memberikan kepastian hukum dikeluarkan ketentuan konversi yang terdapat dalam bagian kedua Undang-Undang Pokok Agraria tentang ketentuan-ketentuan konversi. Istilah eigendom verponding sedikit asing untuk didengar, karena dalam UUPA lebih sering disebut hak eigendom. Verponding sendiri merupakan suatu pajak atas harta tetap disebutkan dalam Pasal 1 Undang-Undang Nomor 33 Tahun 1953 tentang Penetapan "Undang- Undang Darurat Nomor 15 Tahun 1952 untuk Pemungutan Pajak Verponding Tahun-Tahun 1953 dan Berikutnya”.

Dalam Surat Departemen Agraria No. Unda 1/7/39 menyatakan bahwa tanggal kewarganegaraan WNI itu dilihat per 24 September 1960.18 Bila Warga Negara Indonesia hak atas tanah eigendom verponding dalam waktu 6 bulan diharuskan datang ke Kepala Kantor Pendaftaran Tanah (KKPT) untuk dikonversi menjadi hak milik. Namun apabila dalam jangka waktu 6 bulan pemilik hak atas tanah eigendom verponding tidak mendatangi KKPT ataupun tidak dapat membuktikan maka hak eigendom verponding dikonversi menjadi

Agraria Dihubungkan Dengan Pp No. 24 Tahun 1997 Tentang Pendaftaran Tanah."Jurnal Ilmu Hukum Univ. Riau.3 No.1 (2012).

htps://jih.ejournal.unri.ac.id/index.php/】IH/article/view/1030/1023 (diakse s tanggal 4 November 2020)

17 Nathania Febriani dan Endang Pandamdari, "Akibat Hukum Perjanjian Jual Beli Tanah Dengan Hak Eigendom Yang Tidak Dikonversi (Studi Putusan Mahkamah Agung Nomor 756 K/Pdt/2019)" Jurnal Hukum Adigama 3.No.1(2020).https://journal.untar.ac.id/index.php/adigama/article/view/8 898/5691 (diakses 5 November 2020)

18 Elza Syarief, Op.Cit., h.31. 
Hak Guna Bangunan dalam jangka waktu 20 tahun hinga tanggal 24 September 1980. ${ }^{19}$ Namun apabila haknya telah dikonversi menjadi Hak Guna Bangunan maka pemilik hak atas tanah tersebut masih dapat mengubahnya menjadi hak milik. $^{20}$ Sedangkan bagi Warga Negara Asing hak atas tanah eigendom verponding dikonversi menjadi Hak Guna Bagunan. ${ }^{21}$

Apabila setelah 20 tahun UUPA diberlakukan akan tetapi pemilik hak atas tanah eigendom verponding tidak mendaftarkan tanahnya maka tanah tersebut menjadi milik negara. Namun menurut penulis jika setelah 20 tahun UUPA berlaku tanah tersebut tidak sepenuhnya menjadi hak negara. Karena berdasarkan Pasal 24 dan 25 PP Nomor 24 Tahun 1997 tentang Pendaftaran Tanah disebutkan jika pendaftaran tanah yang dilakukan terhadap Badan Pertanahan Nasional yang bersumber dari hak-hak lama salah satunya eigendom verponding dapat dilakukan dan dikonversi menjadi hak milik dengan syarat pemilik harus membuktikan dengan alat bukti yang kuat mengenai hak tanahnya seperti bukti-bukti tertulis, keterangan saksi dan/atau pernyataan. Dan dalam rangka menilai akuratnya alat-alat bukti tersebut dilakukan pengumpulan serta penilaian data yuridis terhadap bidang tanah.

Maka setelah jangka waktu 20 tahun pemilik hak atas tanah dapat mengkonversi menjadi hak milik apabila tanah tersebut tidak digunakan dandimanfaatkan oleh negara untuk kepentingan umum berdasarkan Keputusan Presiden Nomor 32 Tahun 1979 tentang Pokok-Pokok Kebijaksanaan dalam

${ }^{19}$ Peraturan Menteri Agraria Nomor 2 Tahun 1960 tentang Pelaksanaan Ketentuan Undang-Undang Pokok Agraria.

${ }^{20}$ Elza Syarief, Op.Cit., h.31.

21 Nadya Karina, Ana Siviana, dan Triyono "Penyelesaian Sengketa TanahBekas Hak Barat (Recht Van Verponding) dengan Tanah Hak Pakai di Kota Tegal (Studi Kasus Putusan MA Nomor: 1097k/Pdt/2013." $\begin{array}{llllll}\text { Diponogoro Law } & \text { Review } & 5 & \text { No.2 } & \text { (2016). }\end{array}$ ttps://ejournal3.undip.ac.id/index.php/dlr/article/view/11019/10688 (diakses tanggal 6 November 2020). 
Rangka Pemberian Hak Baru Atas Tanah Asal Konversi Hak-Hak Barat. Namun kepada pemilik hak atas tanah eigendom verponding yang telah diambil alih oleh Negara untuk kepentingan umum akan diberikan ganti rugi apabila telah memenuhi bukti-buktinya.

\section{Cara Mengembalikan Hak Atas Tanah Eigendom Verponding yang Dikuasai Pihak Lain}

Sengketa tanah hak-hak atas tanah barat masih saja terjadi dan semakin bertambah salah satunya hak atas tanah eigendom verponding. Karena peraturan untuk melindungi pemilik hak atas tanah eigendom verponding masih tidak jelas hukumnya. Seperti yang akan dibahas yaitu sengketa tanah eigendom verponding yang dikuasai pihak lain.

Pihak yang memiliki hak atas tanah eigendom verponding yang dikuasai pihak lain dan telah disertifikasi oleh Badan Pertanahan Nasional mempunyai hak untuk menuntut kembali hak atas tanah tersebut ditangan siapapun benda itu berada. Karena eigendom verponding merupakan hak atas tanah yang paling kuat dalam hak-hak barat dan berdasarkan UUPA dikonversi menjadi hak milik untuk Warga Negara Indonesia. ${ }^{22}$

Apabila hak atas tanah eigendom verponding dikuasai pihak lain, pemegang hak atas tanah tersebut dapat menggugat dan harus membuktikan ada kesalahan dalam proses penerbitan sertifikat oleh Badan Pertanahan Nasional yang menyebabkan tumpang tindih. ${ }^{23}$ Walaupun telah melewati batas waktu konversi status tanah eigendom verponding masih merupakan alat bukti yang kuat selama belum ada peralihan hak meskipun tanah tersebut telah

22 Hendro, Tesis: "Kekuatan Pembuktian Tanah Eigendom Verponding Menurut Peraturan Pemerintah Nomor 24 Tahun 1997 tentang Pendaftaran Tanah (Analisis Yuridis Terhadap Putusan Peninjauan Kembali Nomor 588 PK./PDT./2002)" (Depok:UI, 2009).

${ }^{23}$ Elza Syarief, Op.Cit., h.114. 
disertifikasi oleh pihak lain. Seperti contohnya pada putusan Nomor 358/ Pdt.G/ 2018? PN. Sby. Dalam putusan tersebut disebutkan eigendom verponding dapat dijadikan alat bukti untuk mengajukan gugatan atas sengketa tanah yang dikuasai pihak lain. Menurut penulis setelah mengajukan gugatan ada baiknya pemilik hak atas tanah eigendom verponding mengubah eigendom verponding menjadi sertifikat hak milik seperti dalam penetapan Nomor 337/ Pdt.P/ 2013/ PN. Jr.

Pemilik hak atas tanah bekas eigendom verponding mempunyai hak untuk menyelesaikan sengketa pertanahannya yang dikuasai pihak lain dengan cara yang sesuai dengan Peraturan Kepala BPN No. 3 Tahun 2011 tentang Pengelolaan, Pengkajian dan Penanganan Kasus Pertanahan terdiri atas: ${ }^{24}$

a. Penyelesaian sengketa dan konflik pertanahan untuk melaksanakan putusan pengadilan;

BPN wajib melaksanakan putusan yang mempunyai kekuatan hukum tetap, maka terhadap pemilik ha katas tanah eigendom verponding berhak mengajukan gugatan ke pengadilan untuk mendapatkan putusan. Lalu BPN yang melaksanakan putusannya tersebut.

b. Penyelesaian sengketa dan konflik pertanahan diluar pengadilan; maka yang dilakukan oleh pihak pemilik eigendom verponding adalah menyelesaikan sengketa dengan cara seperti negosiasi, mediasi dan litigasi. Sehingga BPN berhak untuk melaksanakan hukum administrasi tanah yang terdiri dari:

1) Pembatalan hak atas tanah karena cacat hukum administrasi;

${ }^{24}$ Gita FItriana dan Abdul Mukmin Rehas, "Peran Badan Pertanahan Nasional Kota Samarinda dalam Penyelesaian Sengketa Pertanahan (Ditinjau Berdasarkan Peraturan Kepala Badan Pertanahan Nasional Nomor 3 Tahun 2011 tentang Pengelolaan Pengkajian dan Penanganan Kasus Pertanahan" Yurjska Jurnal Ilmiah Hukum 9, No.2 (2017). http://journal.uwgm.ac.id/index.php/yuriska/article/view/224/171 
2) Pencatatan dalam sertifikat dan/atau Buku Tanah serta Daftar Umum lainnya;dan

3) Penerbitan surat atau keputusan administrasi pertanahan lainnya karena terdapat cacat hukum administrasi dalam penerbitannya.

Maka pemilik eigendom verponding harus mendaftarkan hak atas tanahnya menjadi hak milik ke Badan Pertanahan Nasional dengan prosedur pendaftaran tanah menurut Peraturan Pemerintah Nomor 24 Tahun 1997 sebagai berikut:

a. Pendaftaran tanah secara sporadik dilakukan atas permintaan pihak yang berkepentingan. Pihak yang berkepentingan adalah pihak yang berhak atas bidang tanah yang bersangkutan atau kuasanya. ${ }^{25}$ Pendaftaran tanah dapat dilakukan secara individual atau kolektif.

b. Pembuatan Peta Dasar Pendaftaran. Untuk membuat peta dasar pendaftaran, BPN melaksanakan pemasangan, pengukuran, pemetaan, dan pemeliharaan titik-titik dasar teknik nasional di setiap kabupaten/kota. ${ }^{26}$

c. Penetapan Batas Bidang-bidang Tanah. Bidang tanah yang akan dipetakan dilakukan pengukuran, lalu ditetapkan letak dan batasnya. Penetapan batas bidang tanah dilakukan berdasarkan kesepakatan para pihak yang bersangkutan. ${ }^{27}$

d. Pengukuran dan pemetaan Bidang-bidang tanah dan pembuatan peta pendaftaran. Proses selanjutnya yaitu ditetapkan dalam peta dasar pendaftaran. Namun jika di wilayah tersebut belum ada peta dasar pendaftaran maka dapat menggunakan peta lain dengan memenuhi persyaratan tertentu. ${ }^{28}$

25 Pasal 13 ayat (4) Peraturan Pemerintah Nomor 24 Tahun 1997 tentang Pendaftaran Tanah.

${ }_{26}$ Pasal 15 Peraturan Pemerintah Nomor 24 Tahun 1997 tentang Pendaftaran Tanah.

${ }_{27}$ Pasal 17 ayat (1) dan (2) Peraturan Pemerintah Nomor 24 Tahun 1997 tentang Pendaftaran Tanah

${ }_{28}$ Pasal 2o ayat (1) Peraturan Pemerintah Nomor 24 Tahun 1997 tentang 
e. Pembuatan Daftar tanah. Bidang tanah yang sudah dipetakan dan mempunyai nomor pendaftarannya dalam petanya lalu dibukukan dalam daftar tanah. ${ }^{29}$

f. Pembuatan Surat Ukur. Selajutnya dibuatkan surat ukur untuk syarat dari pendaftaran tanah. ${ }^{30}$

g. Pembuktian hak baru. Pembuktian baru dalam hak atas tanah perlu dilakukan pembuktian agar lebih abasah.

h. Pembuktian hak lama. Untuk tanah yang berasal dari konversi hak-hak lama dibuktikan dengan alat bukti seperti bukti-bukti tertulis, keterangan saksi dan/atau pernyataan yang bersangkutan. ${ }^{31}$

i. Pengumuman data yuridis dan hasil pengukuran. Hasil pengumuman diumumkan dalam waktu 60 hari untuk memberikan kesempatan kepada pihak yang berkaitan mengajukan keberatan pengumuman dilakukan di Kantor Pertanahan kabupaten/kota apabila pihak yang berkaitan merasa keberatan. ${ }^{32}$

j. Pengesahan hasil pengumuman penelitian data fisik dan data yuridis Pengesahan dilakukan dengan catatan mengenai hal-hal yang belum lengkap dan/atau keberatan yang belum diselesaikan.

Menurut penulis penyebab terjadinya kasus eigendom verponding yang dikuasai pihak karena ketidak telitian Badan Pertanahan Nasional dalam menerbitkan Sertifikat. Karena BPN tidak pernah melakukan penyelidikan bidang tanah tersebut dan penetapan batas-batasnya ataupun keliru dalam melakukan penyelidikan bidang tanah tersebut. Dengan ketidak telitian tersebut menyebabkan tumpang tindih dengan pemilik hak atas tanah eigendom

Pendaftaran Tanah.

29 Pasal 21 Peraturan Pemerintah Nomor 24 Tahun 1997 tentang Pendaftaran Tanah.

30 Pasal 22 Peraturan Pemerintah Nomor 24 Tahun 1997 tentang Pendaftaran Tanah.

${ }^{31}$ Pasal 24 ayat (1) Peraturan Pemerintah Nomor 24 Tahun 1997 tentang Pendaftaran Tanah. 32 Urip Santoso,Pendaftaran dan Peralihan Hak Atas Tanah (Jakarta: Kencana,2010), h.180. 
verponding. Tindakan BPN didalam menerbitkan Surat Keputusan yang menjadi objek sengketa tersebut telah mengakibatkan ketidakpastian hukum bagi pemilik sertifikat maupun pemilik hak atas tanah eigendom verponding akan keadaan tanah tersebut karena menyebabkan tumpang tindih. Sesuai dengan salah satu asas yang tercantum dalam Pasal 2 Peraturan Pemerintah No. 24 tahun 1997 tentang Pendaftaran Tanah yaitu asas mutakhir yang memiliki arti memuntut terpeliharanya data pendaftaran tanah secara terus menerus dan berkesinambungan, sehingga data yang ada di Kantor Pertanahan wajib sesuai dengan yang ada di lapangan dan setiap orang dapat memperoleh datanya kapanpun guna terhindar dari tumpang tindih. ${ }^{33}$

\section{KESIMPULAN}

Dari analisis diatas dapat disimpulkan bahwa status tanah eigendom verponding masih merupakan alat bukti yang kuat walaupun telah lewat dari masa konversi selama belum ada peralihan hak meskipun tanah tersebut telah disertifikasi oleh pihak lain. Kekuatan eigendom verponding didaftarkan menjadi hak milik dengan syarat dibuktikan dengan alat bukti seperti alat bukti tertulis, keterangan saksi, dan/atau pernyataan. Cara mengembalikan hak atas tanah eigendom verponding yang dikuasai pihak lain dengan menggugat dan membuktikan ada kesalahan dan ketidaksesuaian dalam proses penerbitan sertifikat yang menimbulkan tumpang tindih. Dan setelah menggugat hak atas tanah miliknya, pemilik eigendom verponding harus mendaftaran hak atas tanahnya menjadi hak milik ke BPN berdasarkan PP Nomor 24 Tahun 1997

33 Yusnita Rachma, "Pelayanan Pendaftaran Tanah Sistematis Lengkap (PTSL) oleh Kantor Pertanahan Kabupaten Pangandaran di Desa Wonoharjo KecamatanPangandaran Kabupaten Pangandaran" Jurnal Moderat 5,No.4(2019).http://jurnal.unigal.ac.id/index.php/moderat/article/view/30 $\underline{64 / 2753}$ (diakeses 7 November 2020) 
tentang Pendaftaran Tanah dimulai ari mendaftarkan tanahnya, pembuatan peta dasar pendaftaran, penetapan batas bidang-bidang tanah, pengukuran dan pemetaan bidang tanah dan pembuatan peta pendaftaran, pembuatan daftar tanah, pembuatan surat ukur, pembuktian hak baru dan hak lama, pengumuman data yuridis dan hasil pengukuran, hingga dilakukan pengesahan hasil pengumuman penelitian data fisik dan data yuridis. Dari kesimpulan tersebut dapat diberikan saran kepada pemilik hak atas tanah eigendom verponding harus menggugat tanahnya yang dikuasai pihak lain dan setelah mendapat putusan harus mengkonversi hak atas tanahnya menjadi hak milik dengan mencantumkan alat bukti yang kuat. Serta kepada pihak BPN untuk lebih teliti dalam menerbitkan sertifikat agar tidak terjadi tumpang tindih dalam kepemilikan hak atas tanah dan dapat mengurangi sengketa pertanahan yang terjadi.

\section{REFERENSI}

\section{a. Buku:}

Isnaeni, Diyan dan Suratman (2018). Reforma Agraria Land Reform dan Redistribusi Tanah di Indonesia. Malang: Intrans Publishing.

Lubis, Abdul Rahim dan Muhammad Yamin Lubis (2008). Hukum Pendaftaran Tanah. Bandung: CV. Mandar Maju.

Lubis, Muhammad Yamin dan Abdul Rahim Lubis (2011), Pencabutan Hak, Pembebasan, dan Pengadaan Tanah. Bandung: CV Mandar Maju.

Rachman, Noer Fauzi (2012). Land Reform Dari Masa Ke Masa. Yogyakarta: Tanah Air Beta.

Rachman, Noer Fauzi (2017). Land Reform dan Gerakan Agraria Indonesia. Yogyakarta: INSISTPress.

Santoso, Urip (2010). Pendaftaran dan Peralihan Hak Atas Tanah. Jakarta: Kencana.

Syarief, Elza (2014). Pensertifikatan Tanah Bekas Hak Eigendom. Jakarta: 
Kepustakaan Populer Gramedia.

\section{b. Jurnal:}

Febriani, Nathania (2020). Akibat Hukum Perjanjian Jual Beli Tanah Dengan Hak Eigendom Yang Tidak DIkonversi (Studi Putusan Mahkamah Agung Nomor 756 K/ PDT/2019). Jurnal Adigama, 3 (1), 205. doi:https://journal.untar.ac.id/index.php/adigama/article/view/8898/56 $\underline{91}$

Fitriana, Gita dan Abdul Mukmin Rehas (2017). Peran Badan Pertanahan Nasional Kota Samarinda dalam Penyelesaian Sengketa Pertanahan (Ditinjau Berdasarkan Peraturan Kepala Badan Pertanahan Nasional Nomor 3 Tahun 2011 tentang Pengelolaan Pengkajian dan Penanganan Kasus Pertanahan.

$\begin{array}{lllll}\text { Yurjska Jurnal Ilmiah } & 9 & \text { (2). }\end{array}$ doi:http://journal.uwgm.ac.id/index.php/yuriska/article/view/224/171 Hasanah,Ulfia (2012). Status Kepemilikan Tanah Hasil Konversi Hak Barat Berdasarkan Uu No. 5 Tahun 1960 Tentang Peraturan Dasar Pokok-Pokok Agraria Dihubungkan Dengan Pp No. 24 Tahun 1997 Tentang Pendaftaran Tanah. Jurnal Ilmu Hukum Univ. Riau, 3 doi:https://jih.ejournal.unri.ac.id/index.php/JIH/article/view/1030/1023 Karina, Nadya, Ana Siviana, dan Triyono (2016). Penyelesaian Sengketa Tanah

Bekas Hak Barat (Recht Van Verponding) dengan Tanah Hak Pakai di Kota Tegal (Studi Kasus Putusan MA Nomor: 1097k/Pdt/2013. Diponogoro Law Review,5(2).

doi:https://ejournal3.undip.ac.id/index.php/dlr/article/view/11019/106 $\underline{88}$

Liadi, William Seven (2019). Kedudukan Eigendom Verponding dalam Hukum Pertanahan di Indonesia. Panorama Hukum, 4 (1), 14. 
doi:http://ejournal.unikama.ac.id/index.php/iph/article/view/3884/236 Muhlizar (2020). Eigendom Verponding Sebagai Alas Hak Dalam Persfektif Undang-Undang Nomor 5 Tahun 1960 tentang Peraturan Dasar PokokPokok Agraria. Hadharah, 12 (1), 90. doi:h ttps://ejurnal.univamedan.ac.id/index.php/Hadharah/article/view/58/44 Mu'in, Achmad (2015). Hak Pemegang Hak Atas Tanah EigendomUntuk Mendapatkan Hak Setelah Habisnya Waktu Sebagaimana Keputusan Presiden Republik Indonesia Nomor 32 Tahun 1979 Tentang PokokPokok Kebijaksanaan Dalam Rangka Pemberian Hak Baru Atas Tanah Asal Konversi Hak-Hak Barat. Calyptra, 4 (1). doi:http://journal.ubaya.ac.id/index.php/jimus/article/view/1020/819 Rachma, Yusnita (2019). Pelayanan Pendaftaran Tanah Sistematis Lengkap (PTSL) oleh Kantor Pertanahan Kabupaten Pangandaran di Desa Wonoharjo KecamatanPangandaran Kabupaten Pangandaran. Jurnal Moderat,5(4). doi: https://jurnal.unigal.ac.id/index.php/moderat/article/view/3064/2753

\section{c. Peraturan Perundang-undangan}

Undang-Undang Dasar Negara Republik Indonesia Tahun 1945

Kitab Undang-Undang Hukum Perdata.

Republik Indonesia, Undang-Undang Peraturan Dasar Pokok-Pokok Agraria, Undang-Undang Nomor 5 tahun 1960, Lembaran Negara Republik Indonesia Tahun 1860 Nomor 104.

Republik Indonesia, Peraturan Pemerintah tentang Pendaftaran Tanah, Peraturan Pemerintah Nomor 24 Tahun 1997, Lembaran Negara Republik Indonesia Tahun 1997 Nomor 59, Tambahan Lembaran Negara Nomor 3696

Republik Indonesia, Keputusan Presiden Tentang Pokok-Pokok Kebijaksanaan Dalam Rangka Pemberian Hak Baru Atas Tanah Asal Konversi Hak-Hak 
Barat. Nomor 32 Tahun 1979, Lembaran Negara Republik Indonesia Tahun 1979.

Republik Indonesia, Peraturan Menteri Agraria Tentang Pelaksanaan Ketentuan Undang-Undang Pokok Agraria. Nomor 2 Tahun 1960, Lembaran Negara Republik Indonesia Tahun 1960.

Republik Indonesia, Peraturan Menteri Dalam Negeri Tentang KetentuanKetentuan Mengenai Permohonan dan Pemberian Hak Baru Atas Tanah Asal Konversi Hak-Hak Barat. Nomor 3 Tahun 1979, Lembaran Negara Republik Indonesia Tahun 1979.

\section{d. Tesis/ Disertasi}

Hendro (2009). Kekuatan Pembuktian Tanah Eigendom Verponding Menurut Peraturan Pemerintah Nomor 24 Tahun 1997 tentang Pendaftaran Tanah (Analisis Yuridis Terhadap Putusan Peninjauan Kembali Nomor 588PK./PDT./2002) Tesis UI.) 